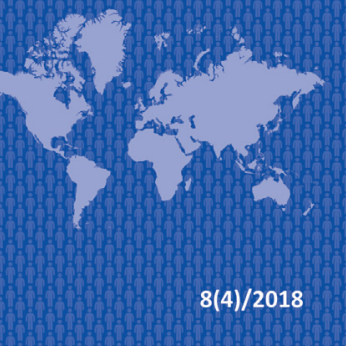

DOI 10.4467/24512249JG.18.028.9015

\title{
EXAMINING COMMON VALUES OF THE INTERNATIONAL CHRISTIAN CENTER (IKC) AND ITS EMPLOYEES
}

\author{
Kourosh Gharagozlou \\ Institute of Applied Social Sciences of the University of Warsaw, Nowy Świat 69, 00-927 Warszawa, Poland \\ e-mail: kouroshfri@gmail.com
}

\section{Citation}

Gharagozlou K., 2018, Examining common values of the International Christian Center (IKC) and its employees, Journal of Geography, Politics and Society, 8(4), 42-52.

\begin{abstract}
The purpose of this research is to identify if there is conflict between employees of IKC who come from masculine or feminine cultural backgrounds. In order to response this question, I focused mainly on methodology, and for the analysis of the data it used qualitative analyses. There is a benefit to study for this research paper, as it helps to communicate better for some people who work with different cultures in a workplace. I am wandering if there is a common value within the group of employees to increase the productivity of IKC. Organizational values overrode cultural background in a religious organization. Hofstede's ranking of countries, on masculine versus feminine traits, had no effect on the level of conflict.
\end{abstract}

\section{Key words}

Cultural identity, workplace values, religion in the workplace, workplace conflict, masculinity and femininity, gender in the workplace

\section{Introduction}

International Christian Center (IKC) is a structure under a larger Christian organization called Indre Mission and also a part of the Danish Church known as "Folkekirken". The Christian organization IKC located in Copenhagen is dedicated to helping foreigners and asylum seekers gain language and cultural skills for Danish Society. Through Christian friends, I got introduced IKC, and I have a personal knowledge of the place as I worked there shortly as a volunteer. It seems obvious to make a study about feminine and masculine culture in an organization such as this, due to the vast variety of backgrounds of the employees here.

From the mid 1980's many refugees came to Denmark and Indre Mission started to assist these immigrants. The counseling is free. IKC is an organization with open doors to everybody regardless of their culture or religion offering opportunities for people of different cultures to meet and socialize. Bible lessons, meditations, and prayers often take place during this socialization process (Indre Missions Tværkulturelle Arbejde). 
The employees at IKC come from different cultural backgrounds from different parts of Europe (Scandinavia and southern Europe), from the Middle East and from the USA. This research paper will examine how the employees with divergent cultural backgrounds come together and develop common cultural values at the IKC workplace, which is informed by Christianity.

In this study, I have collected information from employees working at the organization "IKC". I divided the group into two, in order to have elements from both feminine and masculine cultures because of the different values in their different cultural backgrounds. I interviewed six people, three that come from a masculine culture, namely USA, Italy, and Egypt, while three were from Denmark. The employees in "IKC" have to have the same goals and values as the organization in order to achieve the organization's mission and vision. This can be difficult due to cultural difference.

In the book "Masculinity and femininity, the taboo dimension of national culture", G.H. Hofstede (1998) theorizes about cross-cultural communication, feminine, and masculine cultures but an empirical study needs to be implemented to prove that these cross-gender cultural values are different. The purpose of my study is to investigate further the values in feminine and masculine cultures in the light of the common organization values.

In thiayarticle, I will use the research methodologh that has been defined by K.F. Punch as containing four main points: defining the topic of the research, defining the goal, designing a methodology to achieve that goal, and anticipating the value in the findins" (Punch, 2006, p. 9). My research question ise are there complications, regarding personal values, within employees froa masculine and feminine cultures as they work together in a Christian organization like th "IC?

My hypothesis was that there might be problems between people from masculine and feminine cultures working together. In an organization like IKC you have to ascribe to common values, which can be very difficult for some people.

In order to answer the topic of my research I have used individual interviews, which served as an undisturbed source. These individual interviews gave a deep insight into conversations between employees from feminine cultures and masculine cultures. For example, in the use of individual interviews I was able to explore their personal values regarding IKC. Through this, I was able to find out about the employees worldviews, opinions, ideas and thoughts on cultural values and the common values of IKC. This method helped me to understand the thoughts of the employees of IKC. Furthermore, I wanted to look in to if the employees at IKC despite their feminine or masculine cultural background had some common values, which might come from the organization. The individual interview gave the opportunity for a communicational interaction between the interviewer and interviewee.

In this paper I have tried to find out about the values of people from feminine and masculine cultures in IKC and their common values. As there are both masculine and feminine cultures working together in IKC I have found it interesting to investigate and understand how it is possible for them to work together. I have examined their different cultural backgrounds and values to see how they adapt to the values of IKC in their working life.

The hope in doing this research is that I can learn how to point out factors that will increase the profit for IKC and help to address key points about increasing productivity of IKC. To do this I have tried to find out how people from masculine and feminine cultures can work together in an organization like IKC and apply the values of IKC in the working life.

\section{Theoretical Framewory}

In Masculinity and Femininity: The Taboo Dimension of National Cultures (Hofstede, 1998, p. 6-7) has defined the concept of masculinity as the opposite of femininity. G.H. Hofstede has analyzed cultures along five dimensions: (1) Power distance, (2) Individualism vs. Collectivism (3) masculinity versus femininity (4) Uncertainty avoidance (5) Long-term vs. short-term orientation. I have focused on the singular dimension of Masculinity/Femininity. According to G.H. Hofstede there are several differences between a masculine culture and a feminine culture. In a masculine culture men are far more than women expected to be "assertive, tough, and focused on material success" (Hofstede, 1991, p. 261-262). Women, on the other hand, are expected to represent an ideal that is expressed by being modest, tender, and concerned with the quality of Ife. (Reinisch, 1987).

In contrast to the masculine culture, we have the feminine culture. In the feminine culture the ideal of men and women is more similar. Here, both genders are supposed to be like the women in a masculine culture (Hofstede, 1998). In short, there is not the same separation of how men and women are supposed to be in a feminine culture as in a masculine culture. Larry Samovar also points out that in masculine cultures the biological differences between men and women are used in the definition of men and women's social roles in the society (Bartlett, 
1998). From these ideas, Hofstede has outlined the differences between feminine and masculine societies (appendix 1). I will not outline all the differences here but just show some examples. One of the key differences is that in a masculine society "money and things" are much more important than in a feminine society where they in contrast are more focused on the "relationships between people". In feminine societies it is a general norm that you have a strong sympathy for the weak. In contrast the masculine culture has sympathy for the strong. When you look at the working life one clear difference worth mentioning is that people in a feminine culture "work in order to live" whereas people in a masculine culture "live in order to work" (Hofstede, 1998, p. 16). Supporting this, C. Rodrigues H?. Blumberg (2000) state that an increased job challenge will improve the quality-ofwork-life in a masculine society but in feminine societies an improved quality-of-work-life means an opportunity to develop relationships on the 00 ).

G.H. Hofsted1? 1998, p.92?) has also categorized the different cultures in a nationalistic way in the feminine/masculine divide. In appendix 2, we can see this, where, for example, Denmark features in the fourth position of feminine culture while Japan features in the first position of masculine culture. A quick understanding of this can be gotten from the fact that on average, in Denmark people leave work at $4 \mathrm{pm}$ to take care of their relationships, while in Japan they work longer hours. Following this division, we can see how the people interviewed at IKC are from masculine cultures when from Egypt, Italy and USA - cultures that support the gender gap, while the Danish people represent another culture where care is more expected from both genders.

It seems that IKC community culturally is oriented towards helping people, which according to the above description of masculine and feminine culture tends to be more related to the values of a feminine culture. The Christian organization and its employee's offers free help to people and follow Jesus' teachings.

\section{Qualitative methods}

In this paper I chose to use qualitative research because it makes one able to describe an event in its natural setting. It is a subjective way to look at life as it is lived and an attempt to explain the studied "behaviour" (Silverman, 2006). The research method is typically in the form of words instead of numbers and this method is often presented as 'richer' and 'more valid' compare to quantitative data (Dey, 1993). It has usually been used in the social sciences by researchers in fields like sociology and an organizational study has also used qualitative research as their way of collecting data (Wengraf, 2001). As mentioned qualitative research is usually in the form of words, which makes it "a source of well grounded, rich description and explanation of processes in identifiable local contexts" (Miles, 1994, p. 1). This allows one "to study a phenomena which are simply unavailable elsewhere" (Silverman, 2006, p. 43). Working with qualitative data allows "you the opportunity to identify specifically what kind of meaning people put into a certain phenomena" (Silverman, 2006, p. 44).

In order to response to problem formulation of this paper, it needs to consider on some following questions about this research.

-What kind of phenomenon do you plan to study?

-What do you want to know about the phenomenon?

- What do you want to know about cultural values of the employees who work at IKC?

It seems, conflict, is a phenomenon in an even small society. I would like to find out if there is conflict between employees of the IKC who come from different cultural backgrounds.

The strength of qualitative research is its capability to lead to unexpected findings and hereby to "help researchers to get beyond initial conceptions and do generate or revise conceptual frameworks" (Miles, 1994, p. 1). This was illustrated in the interview process by focusing on the word" help" to describe the differences in meaning amongst the group working at IKC. Through this qualitative method I could better understand the underlying value placed in their individual ideology.

\subsection{Thematic coding}

The aim of an analysis of qualitative data is to characterize the data and afterwards create a basis to infer relations, create understanding and to have insight in human meaning and behavior. Qualitative data is based on cases, examples that will be analyzed in their context. It involves analyzing and interpreting texts and interviews in order to explore meaningful patterns descriptive of a particular phenomenon (Auerbach, 2003).

A case can be a person, a place, an event etc. To do so, one needs to create relevant categories and concepts in relation to the researcher's goal. And creating categories is "the core feature of qualitative analysis" (Lundman, 2004, p. 107). A category here is defined as a group of contents that share cohesion. The qualitative analysis looks both at the picture as a whole and it also identifies meaningful units. The coding of the words can be either explicit or 
implicit. The codes can identify themes allowing for a comparison and generalization (Jensen, 2002). The words can either take the form of "a straightforward category label or a more complex one (e.g., a metaphor)" (Miles, 1994, p. 56). The analysis takes place through the repeated and continuous dialogue with the sources and thereby you develop definitions and categories that form the basis for the conclusions (Jensen, 2002).

The aim of thematic Coding is to find which main "themes" or "topics" can be found in the data I collected. By reading through the various texts (individual), it was possible to identify which themes were mentioned more often and in relation with each other (Seidman, 2015). In the other words, I have created codes, open coding, which codes are suggested by the researcher's examination (Babbie, 2007, p. 385).

There are some themes, which are repeated in several places. I realized that the interviewees explicitly state that there are important. I would also consider to categories those themes, in order to realize which are the most relevant and how these codes are connected to each other.

The reason I chose to use thematic coding as a method is because of its unique capability to interpret the meaning of the interviewee's response (Chesnay, 2014). In my case where they all come from different kinds of cultural backgrounds and with different kinds of values and worldviews I had to understand their opinions on different subjects. To do this I collected the most used themes. For example in the question; "why everybody who comes to "IKC" deserve help?" one of the interviewees' replied that "Even Muhammad Gaddafi could deserves help." In this case I was not sure about the actual meaning behind the statement, and therefore I needed to interpret what the interviewee meant. By interpreting these I was able to point out and understand that the interviewee meant that all people who need help deserve help.

\subsection{Interview}

I conducted interviews with relevant people to pursue this research topic, in deference to Klaus Bruhn Jensen's statement: "It is one of the best ways to find out what people think about the questions you ask them" (Jensen, 2002, p. 240).

With the use of interview as a method there is an active process where the interviewer and interviewee will produce knowledge. This knowledge is produced "in a conversational relation" (Kvale, 2009, p. 19-20). "Interview is a professional conversation and is based on conversations of daily life. The knowledge is constructed in the inter-action between the interviewer and the interviewee" (Kvale, 2009, p. 2).
This means that the knowledge produced in this kind of research method is produced in social interaction between the two parts where there is no "mechanical following of rules and rests upon the interview's skills and situated personal judgment in the posing of questions" (Kvale, 2009, p. 82). The main purpose is to understand the view from the subject's perspective (Willis, 2015). To understand the interviewee's world the interviewer must address questions in order to achieve knowledge and have argument about the logic and truth (Napier, 2010).

In an interview-situation the interviewer can throughout conversations with the interviewee (the subject) extend their understanding of the investigated phenomena. The interview is a key in exploring how people experience and understand the world (Gillham, 2000, p. 10-51). In interviews they can describe in their own words how they experience the world. "Interviews provide a great method of producing knowledge of the human situation" (Kvale, 2007, p. 9).

It is the purpose of the interview to bring new information and aspects forward regarding the studied phenomena and through an analysis of the transcription of the interviews "new distinctions may be discovered" (Kvale, 2009, p. 112).

In my opinion, by conducting interview, the interviewer is able to explore great data, describe central themes, and glend the meanintheof the livld of the subjectn Tthe main task in interviewing is to understand the meaning of what the interviewees say. Interviewing participants could paint a picture of what happened in a specific event, and yield data regarding the interviewees' perspectives about common values of IKC's employees.

\subsection{Data Collection}

The first component of this method was the creation of an interview guide that would be used when interviewing key figures working at IKC (appendix 3). When selecting these individuals I wanted equality in the numbers of participants coming from different cultural values, namely of masculine and feminine cultures, as discussed earlier.

In total I have conducted six individual interviews. Three of them were with people from masculine culture and the rest three were with people from feminine culture. Four of the individual interviews were held face-to-face. The other two, which were supposed to happen face-to-face, were done by email interview to compensate for the fact that they were sick and did not show up at the agreed time. In general, each interview was conducted face-to face and lasted 25 minutes. With such a time, I was able to clarify my questions and they were able to elaborate 
their answers if I had problems understanding them. The main purpose of the individual interviews was to obtain their personal values.

If I would have used focus groups of feminine and masculine cultures it could have been disadvantageous due to members not feeling comfortable stating their minds in front of the other participants. And since this paper's topic is quite sensible to many I decided to use individual interviews in hope to get more reliable information because of a more pleasant environment where the conversation will take place face-to-face by two persons. It also provided a unique access to the lived world of the subjects (Kvale, 2007) and a "professional conversation between interviewer and interviewee" (Kvale, 2009, p. 2).

In obtaining their personal values I found an important value in my first question; why everybody who comes to "IKC" deserves help? One interesting outcome of this method was how one respondent answered: "I try to close my eyes to whatever might be repellent in my neighbor's behaviour." Maybe he would not have answered this way if I asked him the question in a focus group. It is important when asking questions to start from an open and objective position, to which D. Silverman refers "beginning with the how questions". Beginning in this place allows the interviewee to come to their own conclusions unbiased by the subjectivity of the interviewer and then you can gain more contextual information by asking what Silverman refers to as "The why questions" (Silverman, 2006, p. 391).

At IKC, there are 6 employees and about 40 volunteers from different cultural backgrounds, while the employees are all from Denmark. The volunteers teach Danish and English while the employees also teach as well as they counsel immigrants. The people I interviewed were 3 employees and 3 volunteers. Both employees $\&$ volunteers from IKC have different roles at IKC. In this way, I was able to compare their positions and contributions to IKC. They serve a community of "users", who are immigrants who come to IKC, in the least, to get free language education.

The meetings for the individual interviews were very successful. There was a very friendly environment, during the question-session (face-to-face). I made a verbal agreement with all the interviewees from both feminine \& masculine cultures not to write down their names and addresses to preserve anonymity. The entire sets of interviews were recorded with a type-recorder.

\subsection{Data Analysis}

After the data gathered through the interviews, a table was produced (appendix 4). From this analysis, it is possible to categorize and identify several themes. Below, they are presented.

As an example to explain my work -method for identifying themes found in my data, I will explain point 1 . I identified 3 codes from the data gathered through interviews: Obligation, duty, and same opportunity (the purpose of providing, the same opportunity for all). In these three codes I identified the logical common denominator or theme: responsibility.

1) Responsibility (obligation; duty; same opportunity):

Those people who work at IKC have a great responsibility regarding their job. According to IKC vision, they should follow Jesus. They have a duty to work for, and to serve Jesus.

"I feel an obligation to help them" (interviewee 2).

2) Christian caring for all (Love and help; no distinc-

tion by Jesus; all created by God, fellow human beings):

According to Christianity, loving your neighbor is "the way to show that we love God".

"Jesus created us as a crown on his creation. Thus, we were given the responsibility to take care of the world. We are the ones he saves along with all the creation - not the angels" (interviewee 3).

Also your enemies (even repellent)

To follow Jesus, "you are obligated to love and help all people, even your enemies". (interviewee 1)

3) Opinion of users: Strength \& Weakness (motivation and clear goals vs outcasts):

The employees at IKC share common values, but seem to have different ways of looking at the users.

(quote - strong): "my experience with the people I have met at IKC is that most of them are strong, have clear goals for their future, and a strong motivation for reaching their goals" (interviewee 1).

(quote -weak): "In the biblical worldview all people are created by God and are therefore equally valuable. I want to help people in IKC who are usually weak, because they are foreigner \& new to Denmark. Thus, they are usually depended on other" (interviewee 3).

4) Private life and Work life (they should go together; overlapping):

Many of the employees at IKC have Christian values, even though they come from a feminine culture, their work and private life overlap each other.

"There is an overlap between some of my working hours and some of my spare time" (interviewee 2).

5) Relationships are central (share life experiences, identical): 
Both people from feminine and masculine cultures who work at IKC want to share their life with other people, in order to know other people. By doing this, they are able to develop their jo.

"Relationships between people are more valuable than any money or any number of things. It is important to talk to people, get to know them, and be a part of a community of people that you trust and love, and whom love you as well. I believe that an increased job challenge can be beneficial in helping you to grow and learn as a person, but as I said before, I consider relationships to be one of the most important things in life. So for me, the workplace is just another place to get to know peopl". (linterviewee 6).

\section{Discussion}

I have understood that employees who work at "IKC" have sympathy for the weak. It appears that the employees work in order to live and have a belief that they are doing meaningful work; they work with people and try to make their daily life better so people can become happier and able to communicate more fluently by learning the language. Furthermore, it appears that these relationships are very important to IKC. Relationships are very important in many countries and if you work with international people then building relationships is very important.

In relation to the question regarding "helping people who need help" there was a pretty clear consensus that they worked because they wanted to help people, weak \& foreigner, to improve their quality of life. It had nothing to do with doing better to challenge their job. They also mentioned other benefits in their job but they kept returning to the point that they were here to "help others". They were also very focused on that all people, special weak people, should be able to get help - "all people deserve help". They also pointed out that one of the best ways to improve their life is through education and the Christian gospel.

One of the respondents (interviewer 1) from a masculine culture said "most of them are strong, have clear goals for their future, and have a strong motivation for reaching their goals". This contrasts with the ideas that they are "weak". According to Hofstede's theory, it is important for masculine culture to show assertiveness, ambition and competition. Such an overview looks at the ambition and motivation of the users which in the masculine culture constitutes signs of strength. Therefore, some people of masculine cultures relate to the users as strong "sympathy for the strong" (Hofstede, 1998, p. 16). On the other hand, employees of IKC who are from feminine culture relate to users as weak "sympathy for the weak" (Hofstede, 1998, p. 16). This is another overview that looks at not yet acquired competences and relative dependence on others as signs of need for help (for example in communicating with local authorities) which in the values of a feminine culture constitute weakness.

The data explained the part of the theory about "taking care of the weak", that helping weak people are a value of both Christianity \& feminine culture (Hofstede, 1998, p. 16). In a way the two overviews from above are looking at the same phenomenon, but through different 'cultural lengths', either focusing on their strengths or on their weaknesses, the same way that one can focus on the glass being half full or half empty.

Researching the values and common values of IKC by use of interviews was quite revealing, not only of those values, but also about in which ways the theory explained the data, which ways the data accounted for the possible improvement of the theory, or even adding a new perspective for which new theories would be needed.

The responses from the interviewees revealed that Hofstede's theory about feminine \& masculine culture did not specifically apply to their way of working at IKC. Some of the distinctions were more useful than others, such as the distinction between "money and things" and "relationships between people". Through this question it was clear due to the fact that everyone sided with "relationships between people" (Hofstede, 1998, p. 16).

The data showed that the distinction "live to work" / "work to live" is an inappropriate distinction as the respondents struggled to make sense of it. It could be in part, because the theory doesn't account for the much greater complexity of the relationship between life and work "they overlap(linterviewee 2) or because there may be a degree of political correctness in not assuming "live to work". Moreover, in the case of IKC, I would expect fewer "career peopl" (linterviewee 2). It seems that Hofstede's theory was too general concerning the life work balance making it too simplistic. It would be better to also consider on different subcultures as well.

The new themes in the data that have to be accounted for, are those related to Christianity, as most of the common values of this organization rely on what Jesus did and taught. It could be understood that IKC has a specific subculture, because they are so focused on helping refugees (often Musim), where Indre mission as such focuses more on mission inside of Demark. 
Many people who work at IKC come from different religions but they still follow the Christian values from IKC. One can hypothesize that as IKC is an organization, it is the common values that prevail over their personal values. It could be argued that the Christian common values work as mediators at IKC, which perhaps help the collaboration process in their job. This being true, IKC can benefit because the lack of conflicts increases the productivity of IKC.

When working with the interviews, I came to the conclusion that there were themes occurring in the data that were outside of my theoretical framework. Many of the interviewees referred to Christian values as the reason behind their responses. Through the respondents utterances I have found it necessary to develop an adequate theoretical framework surrounding a "Caring in Christianity" theology (Fig. 1). I have realized that I need to consider also another concept that I had not a plan to study in the beginning.

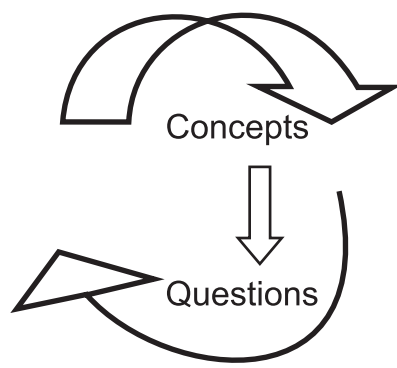

Fig. 1. In thematic interviews, concepts may be raised by the interviewee that prompt the interviewer to form new questions

Source: Dan Pedersen, Associate Professor, Media, Cognition \& Communication, University of Copenhagen, Lecture Empirical Methodologies

In other words, I have explored from the responses of the interviewees that I have to consider on "Caring in Christianity "as well, in order to support the research. As for the use of thematic coding, it was useful to 'understand' the responses, to make meaning from their attitude and experiences about their values and common values.

Even though, it has been interesting to use these theories to understand IKC a much broader study would be necessary to grasp the interplay between feminine \& masculine values and Christianity.

\section{Conclusion}

My initial theoretical framework for interpreting the interview data emphasized the notion of Masculine and Feminine (Hofstede, 1998) cultural as means to examine possible conflicts arising in the workplace of IKC. I made the false assumption that people coming from different cultural backgrounds (Muslim, Buddhist, Sikh, and Non-Religious) would encounter conflicts in the workplace related to the masculine or feminine nature of their culture specifiity. Through the process of dialectical exchange and analyzing the responses from the interviewees, I came to the conclusion that there were themes occurring in the data that were outside of my theoretical framework. Many of the interviewees referred to Christian values as the reason behind their responses. Through the respondents utterances I have come to the conclusion that cultural difference between Masculine \& Feminine culture was overridden by IKCs vision and goals. These provided a framework for a system of common values centering on the notion of "Caring in Christianity". An example I encountered in the research interview that illustrated this was that two of the respondents' work life and private life overlapped. This means, that they couldn't always distinguish between work life and private life. This directly contradicts Hofstede's theory because supposedly in a feminine culture (Denmark) people "work in order to live" instead of "live in order to work". These respondents clearly demonstrated that they exhibited both of these tendencies by overlapping their work lives (going to church \& going on campaigns for the church) with their private lives (going to church \& going on campaigns for the church). In conclusion, this study shows that the common values of IKC (the Christian values) were preponderant over the masculine \& feminine distinction of the background values of the respondents.

Following the rejection of the part of my theory framework mentioned in the discussion, I hereby, in short propose an addition to the framework, that could better account for the data gathered, in order for it to be retested.

For the emerged need of accountinfor a Christian values, I made the following study.

I need to understand, where the values to support people in need comes from.

I will start by listing 3 scriptures fromthe Bbible (the reason for listing them will appear below).

"Love your enemies, and pray for those who persecute you" (Matt. 5,44).

"As you wish, that people should do on to you, you do the same onto them" (Luke 6.31).

"If anybody wants to be first, he should be last of everybody and everybody's servant" (Mark 9, 35b).

The above-mentioned scriptures can be said to summarize the Christian dogma of loving your neighbor. The employees of IKC referred to scriptures such as these in their responses. 
In the following, I will unfold the Christian understanding of the second scripture, also known as "the golden rule", through a theological study by J. Topel 1998) . I wish to underline, that I am not here stating whether or not this Christian understanding represents the truth, I am just saying, that the employees of IKC based their responses to my interview guide on an understanding such as this.

According to the work of J. Topel (1998), the golden rule is a "moral maxim" that is "unique to Jesus". The maxim is a maxim of general altruism, where the individual Christian looks into his own heart, for what he wants, and treats others accordingly. It becomes clear from the biblical context (Luke 6, 2536 ), that this he or she does not do in order to obtain anything, not even reciprocity in action, but as an "imitatio dei" (an imitation of God, who is precisely good to the ungrateful the wicked.

Based on this study you could say, that anybody, who needs help, deserves it, whether it be an enemy, a close friend or relative or a complete stranger.

\section{Refences:}

Auerbach C., 2003, Qualitative Studies in Psychology: Qualitative Data: An Introduction to Coding and Analysis, NYU Press, New York.

Babbie E., 2007, Tile Practice of Social Research, Thomson Wadsworth, Belmont CA.Publisher?, City?.

Bartlett C., 1998, Transcultural Health Care: A Culturally Competent Approach, AORN Journal, 68(3), 479-480.

Chesnay M., 2014, Nursing research using data analysis, qualitative designs and methods in nursing, Springer Publishing Company, New York.

Dey I., 1993, Qualitative data analysis, a user-friendly guide for social scientists, Routledge, London.

Gillham B., 2000, The Research Interview, CPI Antony Rowe, London.

Hofstede G.H., 1991, Cultures and organizations, software of the mind, Intercultural cooperation and its importance for survival, HarperCollins, New York.

Hofstede G.H., 1998, Masculinity and femininity, the taboo dimension of national cultures, Sage Publishing, LondonThousand Oaks.

Hofstede, G.H., 2001, Cultural Consequences: Comparing Values, Behavior, Institutions and Organizations Across Nations, Sage Publishing, London-Thousand Oaks.

Holy Bible. New International Version, 2011, Biblica, Nashville.

Indre Missions Tværkulturelle Arbejde, http://imta.dk/en/ikckbh/interntinal/ [14.12.2017].

Jensen K.B., 2002, A handbook of media and communication research, qualitative and quantitative methodologies, Routledge, London.

Kvale S., 2007, Doing Interviews, Sage Publishing, LondonThousand Oaks.
Kvale S., 2009, Interviews: Learning the Craft of Qualitative Research Interviewing, Sage Publishing, London-Thousand Oaks.

Lundman B., 2004, Qualitative content analysis in nursing research: concepts, procedures and measures to achieve trustworthiness, Nurse Education Today, 24(2), 105-112.

Miles M.B., 1994, Qualitative data analysis an expanded sourcebook, Sage Publishing, New York-Thousand Oaks.

Napier M.R., 2010, Behavior, Truth and Deception: Applying Profiling and Analysis to the Interview Process, CRC Press, London.

Punch K.F., 2006, Developing effective research proposals, Sage Publishing, London.

Reinisch J., 1987, Masculinity/Femininity: Basic Perspectives, Oxford University Press, London.

Rodrigues C., Blumberg H., 2000, Do feminine cultures really behave more feminine than masculine cultures? A comparison of 48 countries femininity-masculinity ranking to their UN human development rankings, Cross Cultural Management: An International Journal, 7(31), 25-34.

Seidman I., 2015, Interviewing as Qualitative Research: A Guide for Researchers in Education and the Social Sciences, Teachers College Press, New York.

Silverman D., 2006, Interpreting qualitative data methods for analyzing talk, text and interaction, Sage Publishing, London.

Topel J. 1998, The tarnished golden rule (Luke 6:31): The inescapable radicalness of Christian ethics, Theological Studies, 59(3), 475-485.

Wengraf T., 2001, Qualitative research interviewing, biographical narrative and semi-structured methods, Sage Publishing, London.

Willis G.B., 2015, Analysis of the Cognitive Interview in Questionnaire Design: Understanding Qualitative Research, Oxford University Press, London. 
Appendix 1. Hofstede's Differences Between Feminine and Masculine Societies

\begin{tabular}{|c|c|c|}
\hline & Feminine & Masculine \\
\hline \multirow[t]{7}{*}{$\begin{array}{l}\text { General } \\
\text { norms }\end{array}$} & $\begin{array}{l}\text { Dominant values in society are caring for others } \\
\text { and preservation }\end{array}$ & $\begin{array}{l}\text { Dominant values in society are material success and } \\
\text { progress }\end{array}$ \\
\hline & People and warm relationships are important & Money and things are important \\
\hline & Everybody is supposed to be modest & $\begin{array}{l}\text { Men are supposed to be assertive, ambitious, and } \\
\text { tough }\end{array}$ \\
\hline & $\begin{array}{l}\text { Both men and women are allowed to be tender and } \\
\text { to be concerned with relationships }\end{array}$ & $\begin{array}{l}\text { Women are supposed to be tender and to take care } \\
\text { of relationships }\end{array}$ \\
\hline & Sympathy for the weak & Sympathy for the strong \\
\hline & Small and slow are beautiful & Big and fast are beautiful \\
\hline & Sex and violence in the media are taboo & Sex in violence in newspapers and on TV \\
\hline \multirow[t]{2}{*}{ In the family } & $\begin{array}{l}\text { Both fathers and mothers deal with facts and feel- } \\
\text { ings }\end{array}$ & $\begin{array}{l}\text { Fathers deal with facts and mothers deal with feel- } \\
\text { ings }\end{array}$ \\
\hline & $\begin{array}{l}\text { Both boys and girls are allowed to cry, but neither } \\
\text { should fight }\end{array}$ & $\begin{array}{l}\text { Girls cry, boys do not; boys should fight back when } \\
\text { attacked, girls should not fight }\end{array}$ \\
\hline \multirow[t]{4}{*}{ In school } & Average student is the norm & Best student is the norm \\
\hline & Failing in school is a minor accident & Failing in school is a disaster \\
\hline & Friendliness in teachers appreciated & Brilliance in teachers appreciated \\
\hline & Boys and girls study same subjects & Boys and girls study different subjects \\
\hline \multirow[t]{2}{*}{ At work } & Work in order to live & Live in order to work \\
\hline & Managers use intuition and strive for consensus & Managers expected to be decisive and assertive \\
\hline
\end{tabular}

Adapted from: Hofstede G.H., 1998, Masculinity and femininity, the taboo dimension of national cultures, Sage Publishing, London-Thousand Oaks, p. 16.

Appendix 2. Top Fifty Most Masculine Countries/Regions

\begin{tabular}{|c|c|c|c|}
\hline Rank & Country & Rank & Country \\
\hline 1 & Japan & $25 / 26$ & Malaysia \\
\hline $2 / 3$ & Austria & 27 & Pakistan \\
\hline $2 / 3$ & Venezuela & 28 & Brazil \\
\hline $4 / 5$ & Italy & 29 & Singapore \\
\hline $4 / 5$ & Switzerland & $30 / 31$ & Israel \\
\hline 6 & Mexico & $30 / 31$ & Indonesia \\
\hline $7 / 8$ & Ireland & $32 / 33$ & Turkey \\
\hline $7 / 8$ & Jamaica & $32 / 33$ & Taiwan \\
\hline $9 / 10$ & Great Britain & 34 & Panama \\
\hline $9 / 10$ & Germany & $35 / 36$ & Iran \\
\hline $11 / 12$ & Philippines & $35 / 36$ & France \\
\hline $11 / 12$ & Colombia & $37 / 38$ & Spain \\
\hline $13 / 14$ & South Africa & $37 / 38$ & Peru \\
\hline $13 / 14$ & Ecuador & 39 & East Africa \\
\hline 15 & United States & 40 & Salvador \\
\hline 16 & Australia & 41 & South Korea \\
\hline 17 & New Zealand & 42 & Uruguay \\
\hline $18 / 19$ & Greece & 43 & Guatemala \\
\hline $18 / 19$ & Hong Kong & 44 & Thailand \\
\hline $20 / 21$ & Argentina & 45 & Portugal \\
\hline $20 / 21$ & India & 46 & Chile \\
\hline 22 & Belgium & 47 & Finland \\
\hline 23 & Arab countries & $48 / 49$ & Yugoslavia \\
\hline 24 & Canada & $48 / 49$ & Costa Rica \\
\hline $25 / 26$ & & 50 & Denmark \\
\hline
\end{tabular}

Adapted from: Hofstede G.H., 2001, Cultural Consequences: Comparing Values, Behavior, Institutions and Organizations Across Nations, Sage Publishing, London-Thousand Oaks. 


\section{Appendix 3. Interview guide:}

1. How does an employee at IKC feel about looking at the world in terms of "money and things" or "relationships between people"?

2. How does an employee at "IKC" view the concept in preferential terms of "an increased job challenge", or "an opportunity to develop relationships on the job"?

3. Why does an employee at IKC have sympathy for others that exhibit weakness?

4. Why is it important as an employee at IKC to "work in order to live" rather than "live in order to work"?

5. Why does everybody who comes to "IKC" deserve help?

\section{Appendix 4. Table Analysis:}

1. Responsibility (obligation; duty; same opportunity).

2. Christian caring for all (Love and help; no distinction by Jesus; all created by God, fellow human beings).

2.1) Also your enemies (even repellent).

3. Opinion of users: Strength \& Weakness (motivation and clear goals vs outcasts).

4. Private life and Work life (they should go together; overlapping).

5. Relationships are central (share life experiences, identical).

\begin{tabular}{|c|c|c|c|c|c|c|}
\hline $\begin{array}{l}\text { Theme } \\
\text { number }\end{array}$ & $\begin{array}{c}\text { Miss: } \\
\text { Number } 1\end{array}$ & $\begin{array}{c}\text { Mr: } \\
\text { Number } 2\end{array}$ & $\begin{array}{c}\text { Miss: } \\
\text { Number } 3\end{array}$ & $\begin{array}{c}\text { Mr: } \\
\text { Number } 4\end{array}$ & $\begin{array}{c}\text { Mr: } \\
\text { Number } 5\end{array}$ & $\begin{array}{c}\text { Miss: } \\
\text { Number } 6\end{array}$ \\
\hline Theme 1 & $\begin{array}{l}\text { "I feel an obliga- } \\
\text { tion to help them" }\end{array}$ & & $\begin{array}{l}\text { 'Duty': “We do } \\
\text { it with care, } \\
\text { energy, deter- } \\
\text { mination" }\end{array}$ & $\begin{array}{l}\text { "I want to help } \\
\text { people that have } \\
\text { not had the same } \\
\text { opportunities in } \\
\text { life as I do" }\end{array}$ & $\begin{array}{c}\text { "The church } \\
\text { has a responsi- } \\
\text { bility" }\end{array}$ & \\
\hline Theme 2 & $\begin{array}{c}\text { "Christian } \\
\text { organization, } \\
\text { Christian values, } \\
\text { love and help all } \\
\text { people" }\end{array}$ & $\begin{array}{l}\text { "Jesus gave spe- } \\
\text { cial attention and } \\
\text { help to the out- } \\
\text { casts of society" }\end{array}$ & $\begin{array}{l}\text { "God tells us } \\
\text { to care for the } \\
\text { weak" }\end{array}$ & $\begin{array}{c}\text { "all people are } \\
\text { created by God } \\
\text { and are there- } \\
\text { fore equally } \\
\text { valuable" } \\
\text { "Everybody } \\
\text { that needs help } \\
\text { deserves help } \\
\text { because we are } \\
\text { all made in Gods } \\
\text { picture" } \\
\end{array}$ & $\begin{array}{l}\text { "we should all } \\
\text { be aware of } \\
\text { our fellow hu- } \\
\text { man beings" }\end{array}$ & $\begin{array}{l}\text { "Love your } \\
\text { neighbor as } \\
\text { yourself" }\end{array}$ \\
\hline Theme 2.1 & $\begin{array}{l}\text { "love and help, } \\
\text { even your en- } \\
\text { emies" }\end{array}$ & $\begin{array}{l}\text { "I try to close my } \\
\text { eyes to whatever } \\
\text { might be repellent } \\
\text { in my neighbour's } \\
\text { behavior and } \\
\text { instead serve him/ } \\
\text { her with the help } \\
\text { and with the word } \\
\text { of God" }\end{array}$ & & & & $\begin{array}{l}\text { “Even Muham- } \\
\text { mad Gaddafi } \\
\text { could de- } \\
\text { serves help" }\end{array}$ \\
\hline Theme 3 & $\begin{array}{l}\text { "most of them } \\
\text { are strong, have } \\
\text { clear goals for } \\
\text { their future, and } \\
\text { a strong motiva- } \\
\text { tion for reaching } \\
\text { their goals" }\end{array}$ & $\begin{array}{l}\text { "Jesus gave special } \\
\text { attention and help } \\
\text { to the outcasts of } \\
\text { society" }\end{array}$ & & & & \\
\hline Theme 4 & $\begin{array}{l}\text { "My job chal- } \\
\text { lenges both my } \\
\text { language skills } \\
\text { and I develop } \\
\text { relationships" }\end{array}$ & $\begin{array}{l}\text { "there is an overlap } \\
\text { between some of } \\
\text { my working hours } \\
\text { and some of my } \\
\text { spare time" }\end{array}$ & $\begin{array}{l}\text { "Work is neces- } \\
\text { sary to live" }\end{array}$ & & $\begin{array}{l}\text { "it's good for } \\
\text { all people to } \\
\text { have jobs." }\end{array}$ & $\begin{array}{c}\text { "our work is } \\
\text { very close to } \\
\text { our personal } \\
\text { life because it } \\
\text { is faith-based } \\
\text { work." }\end{array}$ \\
\hline
\end{tabular}




\begin{tabular}{|l|l|c|c|c|c|}
\hline Theme 5 & & $\begin{array}{c}\text { "IT IS ALL ABOUT } \\
\text { RELATIONSHIPS" }\end{array}$ & & $\begin{array}{c}\text { "It gives essential } \\
\text { meaning when } \\
\text { meeting people } \\
\text { that I can share } \\
\text { life experiences } \\
\text { with" }\end{array}$ & $\begin{array}{c}\text { "Relationships } \\
\text { between peo- } \\
\text { ple are more } \\
\text { valuable than } \\
\text { any money or } \\
\text { any number of } \\
\text { things." } \\
\text { "important } \\
\text { to be part of } \\
\text { a community } \\
\text { of people that } \\
\text { you trust and } \\
\text { love" }\end{array}$ \\
\hline
\end{tabular}

Appendix 5. A presentation of the most interesting (clarifying) responses to the questions from my interview guide (Appendix 3):

(For question number 1): "As a Christian, I try to make sure money and things are not the main focus of my life. Of course we need money to live and we need things to do different tasks, but I believe that everything I have here on earth truly belongs to, and is a gift from God. Relationships between people are more valuable than any money or any number of things. It is important to talk to people, get to know them, and be a part of a community of people that you trust and love, and whom love you as well. But, if you ask me, the most important relationship is the relationship one has with God". (Interviewee number 6)

(For question number 2): "My job situation is quite special as it is ALL ABOUT RELATIONSHIPS so in my situation increased job challenge is IDENTICAL to an opportunity to develop relationships on the job". (Interviewee number 2)

(For question number 3): "Jesus calls us to help that in need, so as a follower of Jesus, I do what He calls me to. We all have weakness in some area, and deep down desire help in those areas. God says: "Love your neighbor as yourself." This means, do for others what you would want to be done for you". (Interviewee number 6)

(For question number 4):" Bringing my family to some of my job functions would be inappropriate but to other job functions very appropriate and therefore there is an overlap between (some of) my working hours and (some of) my spare time making it impossible to answer this question".

(For question number 5): "Everybody that needs help deserves help because we are all made in Gods picture. People don't deserve help because of their education or skills but because they are human beings". 